\title{
Undescended Testis Presenting as Incarcerated Inguinal Hernia in Adults: A Rare Case and Literature Review
}

\author{
Luis Sepúlveda $^{\mathrm{a}} \quad$ Tiago Gorgal $^{\mathrm{a}}$ José Lage ${ }^{\mathrm{b}} \quad$ Ana Monteiro $^{\mathrm{b}} \quad$ Filipe Rodrigues $^{\mathrm{a}}$ \\ aUrology and 'bSurgery Department, Centro Hospitalar de Trás-os-Montes e Alto Douro, Vila Real, Portugal
}

\author{
Key Words \\ Undescended testis • Inguinal hernia • Incarcerated hernia
}

\begin{abstract}
Most cases of undescended testis are asymptomatic and diagnosed in the first years of life. In some rare cases the diagnosis is established during childhood due to sudden torsion of the spermatic cord. Its presence in adults is rare and its precipitance of an acute abdomen or incarcerated inguinal hernia as first clinical manifestation is seldom described in the literature. In this report, we described a case of an elderly male with undescended testis associated with a reactive inflammatory mass incarcerated at the superficial inguinal ring. To the best of our knowledge, this has not been previously described.

Copyright $\odot 2013$ S. Karger AG, Basel
\end{abstract}

\section{Introduction}

Inguinal hernia accounts for $75 \%$ of abdominal wall hernias and is the most common abnormality of the inguinal area $[1,2]$. Incarcerated inguinal hernia, a common surgical indication in the emergency room, occurs when the intra-abdominal contents become trapped in the narrow space at the external or internal ring, preventing reduction. This results in edema and compromised blood flow that may result in necrosis if not relieved. We describe a case of an elderly patient with an unknown undescended testis presenting as an incarcerated inguinal hernia. In case of sudden painful inguinal mass in a patient with an ipsilateral empty hemiscrotum surgeons need to consider the possibility of torsion or incarceration of an undescended testis.

\section{Case Report}

A 63-year-old male presented to our emergency department with sudden right groin pain developed after heavy work. On examination, a non-reducible, mildly painful swelling mass was present in the right groin. No testicle was palpable in the ipsilateral hemiscrotum and the patient admitted to have never been aware of his right gonad, which is indicative of a congenital undescended testis. Full blood count, biochemical investigations, and tumor markers including alpha fetoprotein, lactate dehydrogenase, and beta human chorionic gonadotropin were all within the normal range. Surgical exploration revealed an atrophic testis, enlarged edematous epididymis, and prominent paratesticular mass strangulated in the superficial inguinal ring (fig. 1,2). There was also a diffusely weak inguinal floor. An orchiectomy and Lichtenstein polypropylene mesh repair were performed. The histological examination revealed an atrophic testicle with Leydig cells hyperplasia, enlarged edematous ephididimis, and diffuse acute inflammatory lesions and vascular congestion of the prominent fibroadipose paratesticular tissues. There was no malignant tumor identified in the surgical specimen. The patient was discharged on postoperative day 2 after an uneventful hospital course.

\section{KARGER}

Fax +4161306 1234

E-Mail karger@karger.ch

www.karger.com
(C) 2013 S. Karger AG, Basel

1015-9770/13/0074-0214\$38.00/0

Accessible online at:

www.karger.com/cur
Luis Sepúlveda

Urology Department, Centro Hospitalar de Trás-os-Montes e Alto Douro Avenida da Noruega

PT-5000-508 Vila Real (Portugal)

E-Mail LuisSepulveda.Uro@gmail.com 


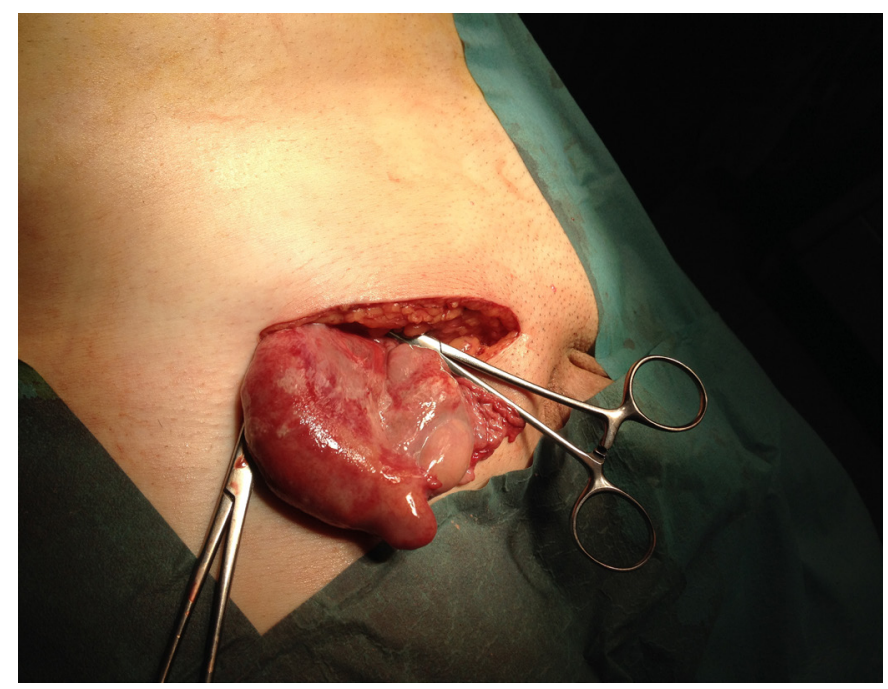

Fig. 1. Atrophic testicle associated with an enlarged edematous epididymis and surrounded by prominent fibroadipose connective tissue.

\section{Discussion}

Undescended testis is the commonest genital malformation in male infants, affecting 2 to $5 \%$ of full-term boys and up to $1 / 3$ rd of premature boys $[3,4]$.

Most cases are diagnosed in the first weeks of life, either by the pediatrician during physical examination or by the family. Watchful waiting is indicated in the first 6 months of life, since spontaneous descent is likely to occur during this period. The incidence of undescended testis drops to about $1 \%$ at 1 year of age $[4,5]$. In the event of non-descent, treatment should ideally be completed at 12 months of age or 18 months at the latest, either by hormonal and/or surgical modalities [3, 4]. The main complications of late treatment are reduced fertility and increased risk of testicular malignancy [3]. Early treatment can potentially minimize the risk of infertility and favors early detection of malignancy by enabling self-examination of the testicle. It is still unclear whether orchiopexy affects the natural history of testicular cancer development. Recent studies show that prepurbertal surgery may in fact protect against the increased risk of testicular cancer associated with cryptorchidism [6-8].

Despite most patients being diagnosed in young age, there are still sparse cases of late diagnosis, including adults. The case presented documents an unexpected finding of an atrophic undescended testis surrounded by

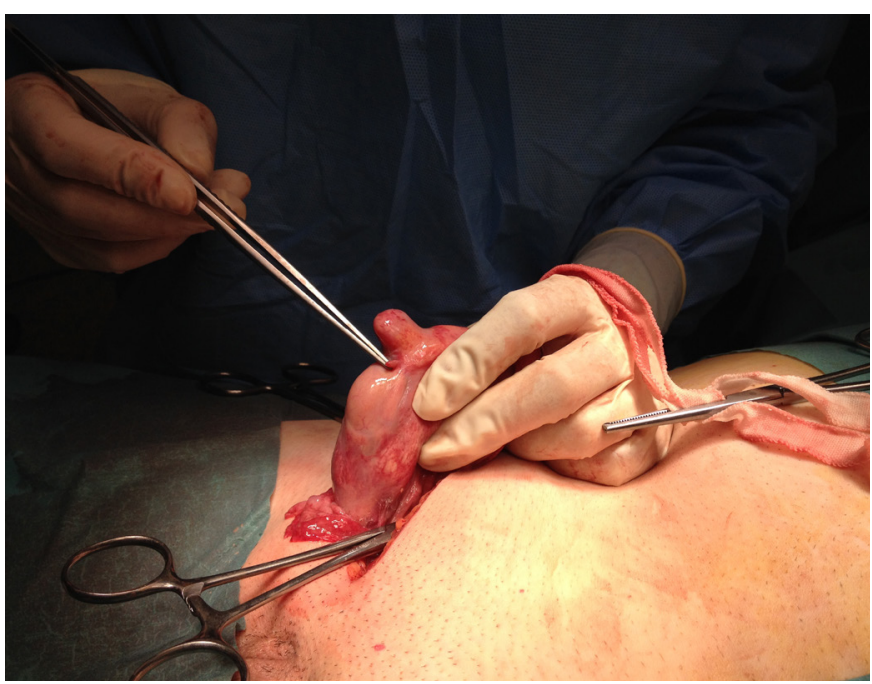

Fig. 2. Identification of hydatid of Morgagni raised the suspicion of right undescended testis incarcerated in the superficial inguinal ring.

an inflammatory paratesticular mass strangulated in the superficial inguinal ring. The authors believe that a sudden increase in the intra-abdominal pressure forced the gonad and involved tissues to travel along the inguinal canal and ultimately to strangulate in the superficial inguinal ring. Our case is particularly notable because it occurred in an elderly man, previously asymptomatic. Despite the congenital absence of the right gonad, neither the patient nor his family seemed to be particularly concerned with this fact. Several rare entities can mimic incarcerated inguinal hernia in men with an undescended testis such as torsion of the spermatic cord, transverse testicular ectopia, omental incarceration of an intra-abdominal testicle, or malignancy of the undescended testis [5, 9-14]. Our review of the literature has failed to reveal any previous reports of an elderly patient with cryptorchid atrophic testicle and enlarged connective tissues incarcerated in the superficial inguinal ring. We conclude that although very unlikely, strangulation of an undescended testis should be considered as part of the differential diagnosis in patients with sudden incarcerated inguinal hernia and an empty ipsilateral hemiscrotum. 


\section{References}

-1 Jenkins JT, O'Dwyer PJ: Inguinal hernias. BMJ 2008;336:269-272.

2 Salemis NS, Karagkiouzis G, Sambaziotis D, Tsiambas E: Large dermoid cyst of the spermatic cord presenting as an incarcerated hernia: a rare presentation and literature review. Hernia 2010;14:321-323.

-3 Mathers MJ, Sperling H, Rübben H, Roth S: The undescended testis: diagnosis, treatment and long-term consequences. Dtsch Arztebl Int 2009;106:527-532.

4 Barthold JS: Abnormalities of the testis and scrotum and their surgical management; in: Wein AJ, Kavoussi LR, Novick AC, Partin AW, Peters CA (eds): Campbell-Walsh Urology, ed 10. Elsevier Saunders, 2012, pp3557 -3574 .
-5 Weiss AP, Van Heukelom J: Torsion of an undescended testis located in the inguinal canal. J Emerg Med 2012;42:538-539.

6 Chan E, Wayne C, Nasr A: Ideal timing of orchiopexy: a systematic review. Pediatr Surg Int 2014;30:80-87.

7 Wood HM, Elder JS: Cryptorchidism and testicular cancer: separating fact from fiction. J Urol 2009;181:452-461.

-8 Walsh TJ, Dall'Era MA, Croughan MS, Carroll PR, Turek PJ: Prepubertal orchiopexy for cryptorchidism may be associated with lower risk of testicular cancer. J Urol 2007;178: 1440-1446.

-9 Shirakawa H, Kozakai N, Sugiura H, Hara S: Torsion of a testicular cancer in cryptorchidism prolapsing out of the inguinal canal: a case report. Hinyokika Kiyo 2009;55:783785 .
10 Rabii R, Rais H, Hafiani M, Dassouli BE, Bennani S, el Mrini M, Benjelloun S: Torsion of an undescended testis. Apropos of a case. Ann Urol (Paris) 1998;32:49-51.

11 Pogorelic Z, Mrklic I, Juric I, Biocic M, Furlan D: Testicular torsion in the inguinal canal in children. J Pediatr Urol 2013;9:793-797.

12 Marx RJ, Zambrano J: A case report: an adult with omental incarceration of a testicle, an unexpected finding at herniorraphy. Mil Med 2009;174:322-323.

13 Kaul A, Srivastava KN, Rehman SM, Goel V, Yadav V: Persistent Müllerian duct syndrome with transverse testicular ectopia presenting as an incarcerated inguinal hernia. Hernia 2011;15:701-704.

14 Kuwayama DP, Peterson JE: Transverse testicular ectopia in a fertile elderly male presenting with incarcerated inguinoscrotal hernia. Hernia 2008;12:313-315. 